\title{
Investing in the Early Years During COVID-19
}

Young children need comprehensive nurturing care which includes good health, adequate nutrition, early learning opportunities, responsive caregiving, and safety and security. Severe, lifelong impacts can result from deprivations during the early years if children do not have these critical inputs to ensure optimal child development.

The World Bank's Investing in the Early Years framework (figure 1) lays out three pillars to ensure children reach their full potential:

i. $\quad$ Children are healthy and well-nourished, especially in the first 1,000 days

ii. Children receive early stimulation and learning opportunities

iii. Children are nurtured and protected from stress

In the following three pages, we set out specific risks that children face under each of these pillars due to the COVID-19 crisis, together with response options, potential platforms and country examples. While health and nutrition are key elements of the COVID-19 emergency response and are more likely to be addressed immediately, empowering parents to provide warm and responsive caregiving and ensuring safety and security of young children and early learning opportunities for young children is essential and risks falling through the cracks.

Figure 1: Investing in the Early Years Framework

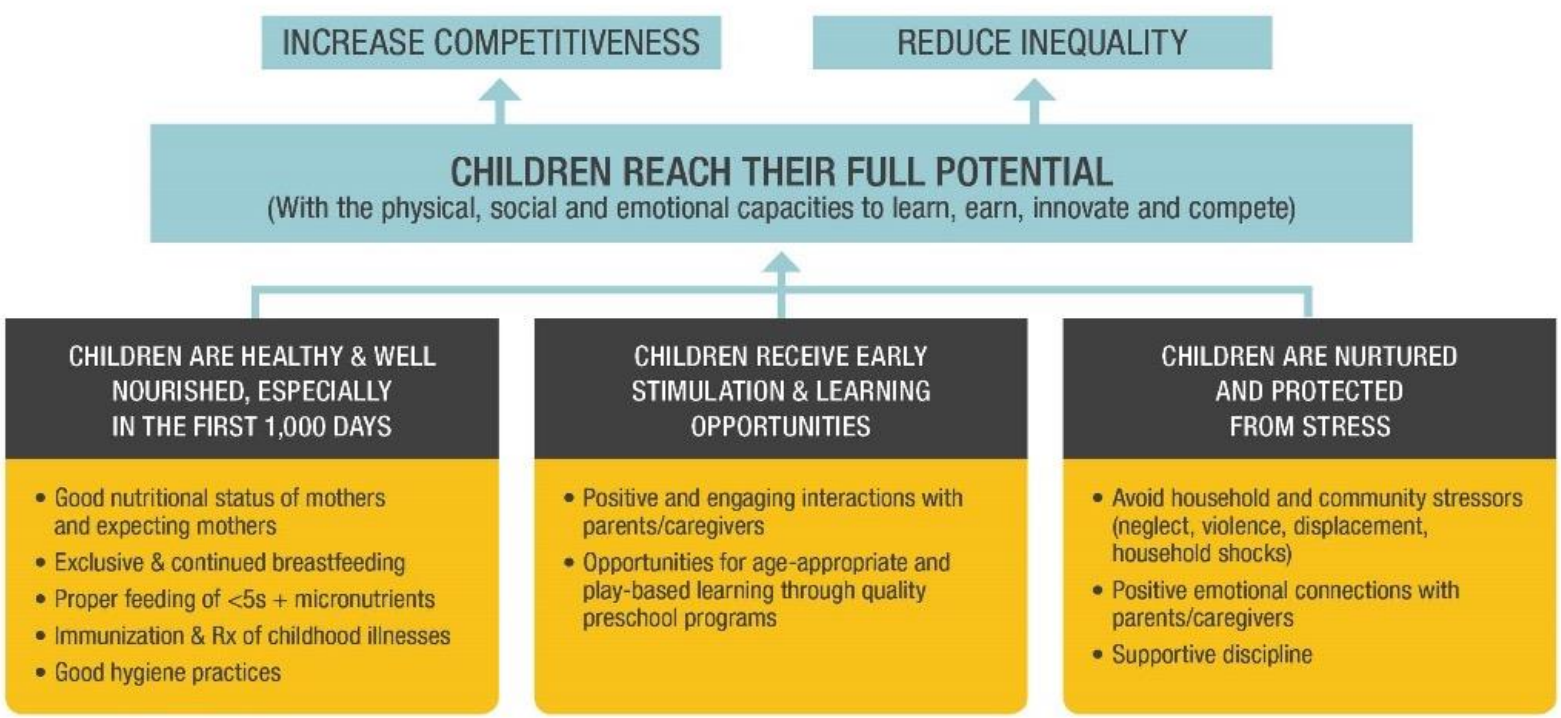

\section{DELIVERING ON THE ESSENTIAL INTERVENTIONS ABOVE REQUIRES EFFORTS ACROSS SECTORS}
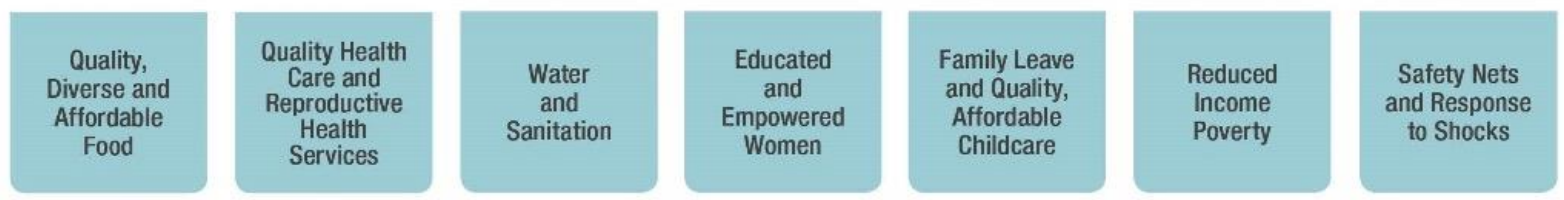


\begin{tabular}{|c|c|c|}
\hline \multicolumn{3}{|c|}{ Early Years Pillar 1: Adequate nutrition and health for children and pregnant women } \\
\hline \multicolumn{3}{|c|}{$\begin{array}{l}\text { - A mother with access to good nutrition and healthcare during pregnancy supports the healthy development of her baby. } \\
\text { - Exclusive breastfeeding for six months and then continued breastfeeding and appropriate complementary feeding with nutritious foods supports } \\
\text { healthy growth and development of children's bodies and brains. } \\
\text { - Good hygiene practices, including hand washing and safe handling of food, are important preventive measures for child health and nutrition. } \\
\text { - A physically and mentally healthy caregiver helps ensure the child's survival and overall development. }\end{array}$} \\
\hline VID-19 & ons & Platforms that can be leveraged: \\
\hline \multirow{2}{*}{$\begin{array}{l}\text { Reduced access to basic health and } \\
\text { nutrition services for pregnant women } \\
\text { and young children, including } \\
\text { promotion and support for optimal } \\
\text { infant and young child feeding }\end{array}$} & \multirow{2}{*}{$\begin{array}{l}\text { Childcare and support for frontline workers } \\
\text { - Provision of temporary, targeted childcare for frontline workers that provides children } \\
\text { with a safe and stimulating environment } \\
\text { - Childcare workers recognized as frontline workers themselves requiring healthcare and } \\
\text { protection to reduce exposure to Covid-19 }\end{array}$} & $\begin{array}{l}\text { Health and nutrition platforms to } \\
\text { ensure continuity of nutrition and } \\
\text { health services and provide messaging } \\
\text { to parents. }\end{array}$ \\
\hline & & $\begin{array}{l}\text { Engage the private sector by drawing } \\
\text { on informal workers including food } \\
\text { processors and food vendors to reach } \\
\text { low income communities. }\end{array}$ \\
\hline \multirow{2}{*}{$\begin{array}{l}\text { - Reduced access to key clinical nutrition } \\
\text { services including } \\
\text { assessment/treatment for } \\
\text { undernutrition, including moderate } \\
\text { and severe acute malnutrition } \\
\text { (wasting), can exacerbate challenges to } \\
\text { child health and nutrition due to lost } \\
\text { income and food supply disruptions } \\
\text { caused by the pandemic. }\end{array}$} & \multirow{2}{*}{$\begin{array}{l}\text { Health } \\
\text { - Prioritize delivery of preventive health (Including routine immunizations) to mitigate } \\
\text { the impact of the pandemic on young children } \\
\text { - Enhance early detection and treatment of child wasting including in-patient care } \\
\text { Nutrition } \\
\text { - Emergency food delivery, including micronutrient and ready-to-use therapeutic food } \\
\text { - supplements for pregnant women and young children } \\
\text { - Enhanced forecasting of critical nutrition supplies } \\
\text { - Cash transfers to compensate for loss of livelihoods, including suspension of conditions } \\
\text { - Adapt school feeding programs to deliver food directly to the community }\end{array}$} & \\
\hline & & $\begin{array}{l}\text { lare } \\
\text { ition and } \\
\text { :asing } \\
\text { to ensure } \\
\text { ose }\end{array}$ \\
\hline \multirow{2}{*}{$\begin{array}{l}\text { Reduced household incomes limiting } \\
\text { access to food and basic utilities such } \\
\text { as electricity, water, } \\
\text { telecommunications etc. }\end{array}$} & \multirow{2}{*}{$\begin{array}{l}\text { Empower parents to protect their children } \\
\text { - Support parents to recognize signs of illness, seek medical attention and promote } \\
\text { family handwashing and hygiene, alternatives to soap and running water as needed } \\
\text { - Provide counseling/problem-solving to parents on optimal infant and young child } \\
\text { feeding and care including feeding of infants and young children during illness }\end{array}$} & $\begin{array}{l}\text { nes to message } \\
\text { nd nutrition. } \\
\text { areas with low }\end{array}$ \\
\hline & & \\
\hline \multicolumn{3}{|c|}{$\begin{array}{l}\text { ountry and program examples, you can click on to find more information: } \\
\text { - Ecuador texting for nutrition } \\
\text { - } \text { Peru approach to halving stunting rates (includes strong information campaign) } \\
\text { - } \text { Mexico online platform for sharing information on COVID-19 }\end{array}$} \\
\hline
\end{tabular}


- Opportunities to learn and play with parents and siblings from birth also support growth and development.

- Access to quality ECE provides children with the building blocks for future success in school and helps develop socio-emotional and cognitive skills.

This is especially true for vulnerable children.

\begin{tabular}{|c|c|c|}
\hline Risks during COVID-19 & Response Options & Platforms that can be leveraged: \\
\hline \multirow{6}{*}{$\begin{array}{l}\text { - Young children who would normally be } \\
\text { attending center-based ECE will lose } \\
\text { learning opportunities as schools close. }\end{array}$} & \multirow{6}{*}{$\begin{array}{l}\text { Childcare } \\
\text { - Provision of temporary, targeted childcare for frontline workers that provides } \\
\text { children with a safe and stimulating environment (but without setting quality } \\
\text { - } \text { standards so high that they cannot be met) } \\
\text { Childcare workers recognized as frontline workers themselves requiring access to } \\
\text { Ensure early learning is part of basic education system responses } \\
\text { - Adapt content and learning material for remote delivery to young children } \\
\text { - Up-skill the existing ECE workforce through virtual learning opportunities. } \\
\text { - Engage private sector schools to ensure they continue to provide learning } \\
\text { opportunities and can be sustained without fees being paid } \\
\text { Maximize opportunities to engage parents in early learning across sectoral platforms } \\
\text { - Provide specific support to parents to engage in early stimulation with children } \\
\text { - Deliver picture books, early learning kits and play materials if risk of infection is low, } \\
\text { piggybacking on feeding and health programs } \\
\text { - Use radio, TV and mobile to reach homes with learning opportunities for children } \\
\text { and support for parents. } \\
\text { - Once schools re-open } \\
\text { - Ensure ECE is included in mass re-enrollment campaigns }\end{array}$} & $\begin{array}{l}\text { Health and nutrition platforms used } \\
\text { to deliver information and messaging } \\
\text { to parents, eg waiting rooms, in } \\
\text { addition to books and play materials. }\end{array}$ \\
\hline & & $\begin{array}{l}\text { Television for educational programs, } \\
\text { like Sesame Street, which have } \\
\text { significant impacts on child } \\
\text { development outcomes. }\end{array}$ \\
\hline & & $\begin{array}{l}\text { Online platforms including attaching } \\
\text { preschool programming to existing } \\
\text { basic education platforms. }\end{array}$ \\
\hline & & $\begin{array}{l}\text { Cash transfer programs to share } \\
\text { messages with parents on early } \\
\text { stimulation and distribute learning } \\
\text { and play materials }\end{array}$ \\
\hline & & $\begin{array}{l}\text { Radio and Interactive audio } \\
\text { instruction can reach parents and } \\
\text { children with entertainment and } \\
\text { learning activities to promote early } \\
\text { learning, }\end{array}$ \\
\hline & & $\begin{array}{l}\text { Mobile phones used to share } \\
\text { messaging with parents on early } \\
\text { stimulation through texting, } \\
\text { whatsapp and call centers. }\end{array}$ \\
\hline \multicolumn{3}{|c|}{$\begin{array}{l}\text { Country and program examples, you can click on to find more information: } \\
\text { - Yunnan, China online resource for ECE teachers and parents } \\
\text { - Colombia strategy for contact without infection early learning services } \\
\text { - } \text { Interactive Audio Instruction in the DRC } \\
\text { - Kenya, engaging parents to promote early literacy }\end{array}$} \\
\hline
\end{tabular}


- Consistent, responsive and positive interactions between parents/caregivers and children- or early stimulation -builds resilience and potential in young children. This protective relationship shields young children from the effects of shocks.

- Protection against sources of stress, including poverty, violence, abuse, neglect and isolation enables children to grow and develop healthily even in the face of adversity.

Risks during COVID-19

- In times of prolonged adversity, it is even more important to support parents with strategies for responsive caregiving to protect children from toxic stress which impedes growth and development.

- The economic impacts of the pandemic on households' income will strain their capacities to invest in their children

- Caregivers might get sick or called away to care for a sick relative.

- Caregivers' mental health at-risk due to multiple stresses related to economic loss, illness, anxiety and fear, other during the COVID-19 crisis.

- Children at higher risk of witnessing or experiencing violence, abuse or neglect, particularly in quarantine.
Response Options

Empower parents to protect their children and themselves

- Help parents understand the potential of responsive caregiving to protect their children and promote healthy development (even in the face of reduced access to nutrition, health and other essential services)

- Adapt and distribute materials for parents with (i) own stress coping strategies, (ii) non-violent parenting activities, and (ii) strategies to protect their children from toxic stress.

- Set up hotlines and text messaging services for women and children experiencing violence and abuse

- Ensure women and children are aware of avenues for protection from violence

Social protection

- Expand safety net coverage and benefit levels to address loss of livelihoods, increased costs.

- Adapt cash transfer program design to orient the use of cash and protect human capital (e.g. suspension of conditions, behavioral communications,

suspending/altering work requirements, and providing social support including food provision and childcare as a cash for work option).

\section{Health and community responses}

Train/provide information to frontline workers on COVID-19 related child protection issues
Platforms that can be leveraged:

Existing health and nutrition platforms

used to deliver information and messaging to parents, eg waiting rooms Television used to share messaging on coping, parenting strategies and avenues for protection for women and children

Websites and Social media used to

share messaging on coping, parenting strategies and avenues for protection

for women and children

Mobile phones texting, whatsapp and

call centers can be used to share messaging with parents on coping. Hotlines can be provided to women and children experiencing violence and abuse.

Cash transfer programs used to share messaging to parents on coping and parenting strategies

Radio used to share messaging on coping, parenting strategies and avenues for protection for women and children

Information campaigns by integrating

messaging related to parenting and coping into campaigns on COVID-19

Country and program examples you can click on to find more information:

- Nicaragua texts to caregivers on parenting

- Madagascar cash transfer program with parenting support

- Mexico hotlines for women suffering from domestic violence 